\title{
Mediální kurace jako praxe paměti: Situační analýza mnemonických praxí mládeže
}

\author{
TOMÁŠ KARGER*
}

\author{
Media Curation as a Practice of Memory: Situational Analysis of Youth's \\ Mnemonic Practices
}

\begin{abstract}
This study focuses on the modalities of transmission of history-related knowledge to a current young generation (12-25 years old). Data from 11 focus groups with pupils and students of schools at the primary, secondary and tertiary levels were used to analyse situations of knowledge transmission with regard to four significant historical events: September 11th 2001, November 17th 1989, August 21th 1968 and February 25th 1948. The study introduces media curation as a senzitizing concept suitable for grapsing the selective dimension of mnemonic practices. The analysis is focused on aspects of expert, social, or data-based curation in situations where mnemonic content is transmitted. This analytical instrument is used in the study to account for situations in which mnemonic practices of the informants take place.
\end{abstract}

Keywords: collective memory; mnemonic practice; situational analysis; curation; media curation

DOI: $10.14712 / 23363525.2019 .3$

\section{Úvod}

V roce 2007 si v monotematickém čísle časopisu Symbolic Interaction, věnujícímu se kolektivní paměti, položili Gary Fine a Aaron Beim [Fine - Beim 2007] několik otázek, které měly sloužit jako vodítka pro interakcionistické přístupy zkoumající tento jev. Fine a Beim se tehdy ptali po tom, jestli konceptualizovat kolektivní pamět jako proces předávání představ o minulosti, nebo jako jeho výsledek; jestli působení kolektivní paměti přičítat charakteristikám jí vlastním, nebo způsobům jejího zprostředkování; a jestli je kolektivní pamět předávána médii, nebo spíše př́mým kontaktem mezi aktéry. Tuzemský výzkum věnující se fenoménu kolektivní paměti i přes svou intenzitu v poslední dekádě, jak se zdá, pokrývá jen některé aspekty těchto otázek.

Výchozí př́stup mnoha autorek a autorů zkoumajících fenomén kolektivní paměti v českém prostředí je vyvozen $\mathrm{z}$ díla Maurice Halbwachse a ústí ve ztotožňování paměti s významovými strukturami obsahujícími sdílené představy o minulosti. V tomto duchu konceptualizoval Jiří Šubrt kolektivní pamět pomocí Parsonsova AGIL modelu jako analytickou kategorii vymezenou vůči zkušenostem, ideologiím a vědeckému poznání [Šubrt Pfeiferová 2010b, 2010a; Šubrt - Vinopal 2010]. S odkazem na Jeffreyho Alexandra, jednoho z Parsonsových pokračovatelů, pak Gábor Oláh explicitně rámuje své zkoumání kolektivní paměti do teze o autonomii kultury, která mu umožňuje vysvětlovat sociální jevy

\footnotetext{
" Mgr. Tomáš Karger, Ph.D., Centrum výzkumu, Fakulta humanitních studií, Univerzita Tomáše Bati, Štefánikova 5670, 76001 Zlín. E-mail: karger@utb.cz.
} 
pomocí analýzy sdílených významů [Oláh 2013]. Podobná východiska lze sledovat také u mnohých dalších empirických studií kolektivní paměti. ${ }^{1}$ Je tedy možné říci, že výzkumné strategie, které k paměti přistupují jako k relativně stabilní významové struktuře (výsledku procesu ve slovníku výše uvedených zcitlivujících otázek), a které si kladou za cíl zkoumat obsah sdílených představ o minulosti (tedy inherentní kvality významových struktur) jsou $\mathrm{v}$ českém prostř̌edí poměrně rozšířené.

Existují ale i výzkumy, které poskytují základní informace o tom, jakými informačními kanály jsou představy o minulosti aktérům zprostředkovávány [například Kunštát 2010]. V tomto ohledu je př́nosný především nedávný výzkum historického vědomí Jiř́ho Šubrta a jeho týmu [Šubrt - Vinopal 2013; Šubrt - Vinopal - Vávra 2013]. Téma informačních zdrojů v rámci tohoto výzkumu zpracoval Martin Vávra [2013], který jako nejvýznamnější z nich identifikuje prolínající se trojici televizního vysílání, historických filmů a filmů dokumentárních. Škola se v tomto ohledu ukazuje být podobně významný zdroj, jako je televizní vysílání samotné. Dle očekávání také internet patří mezi populární informační zdroje, je ovšem specifický velkým podílem aktérů, kteří ho nepoužívají vůbec. Při bližším pohledu Vávra tento stav vysvětluje diferenciací užívání internetu, v němž hrají zásadní roli faktory v podobě věku a vzdělání [Vávra 2013: 41]. Do podobné oblasti spadá také výzkum Denisy Labischové a jejího týmu [Gracová - Labischová 2012; Labischová 2012], který se zaměřuje specifičtěji na učitele, žáky a studenty. Tento výzkum potvrzuje význam audiovizuálních médií v čele s dokumentárními filmy pro vytváření představ o minulosti [Labischová 2012: 153].

Výše uvedené výzkumy poukazují na informační zdroje, které jsou aktéry identifikovány jako významné v souvislosti se získáváním představ o minulosti, ale neposkytují podrobnější informace o tom, jak jsou tyto informační zdroje aktéry využívány. Informační zdroje, které výše uvedené výzkumy implicitně konceptualizují jako vzájemně se vylučující kategorie, se mnohou v praxi navzájem prostupovat (například při pouštění dokumentárních filmů ve školním vyučování, čtení novinových článků na internetu, nebo při vyprávění v reakci na společně sledovaný seriál). Řečeno spolu s Jakubem Mackem [2015: 47], praxe využívání informačních zdrojů tvoří „mediální celky“. Bylo by tedy přínosné podrobněji popsat situace a identifikovat typické praxe využívání informačních zdrojů a jejich kombinací.

V reakci na tento stav badatelského pole je obecným cílem této studie podílet se na doplňování vědění o aspektech výše uvedených zcitlivujících otázek, které zatím nejsou tak dobře pokryty. Jedná se především o otázky týkající se 1) způsobů zprostředkování kolektivní paměti a 2) rolí, jaké v tomto procesu hrají média, vzdělávací instituce a přímá interpersonální komunikace. Tento text je založen na datech z 11 ohniskových skupin se studenty a studentkami na všech třech úrovních formálního vzdělávacího systému. Volba informantů pro ohniskové skupiny je založena na předpokladu, že tito aktéři jsou nositeli nových mediálních praxí (jimž se budu věnovat v následující části textu) a zároveň se nachází v situaci, která je charakteristická předáváním představ o minulosti, at již

1 Mezi dalšími př́iklady mohu uvést studii Olgy Šmídové [2010], ve které jsou kolektivní rámce paměti ztotožňovány se sdílenými představami, studii Gergely Kunta [2013], jež pracuje s konceptem interpretací, jakožto s ustálenými významy, př́ípadně studii Petry Burzové a kolektivu [2013], ve které hraje podobnou roli koncept reprezentací. Podrobněji se strategiemi vysvětlování fenoménu kolektivní paměti v českém prostředí věnuje Karger [2017]. 
formálními (školní vyučování), či neformálními (vyprávění v rodině) prostředky. Konkrétním cílem této studie pak je na základě výpovědí informantů analyzovat situace, v nichž dochází ke vzpomínání a předávání vzpomínek. K tomuto účelu bylo využito mapování předávání představ o významných historických událostech, přičemž text sleduje logiku jednotlivých typů kuračních praxí, jak budou představeny níže.

\section{Od kolektivní paměti k současné mediální praxi}

Výzkum kolektivní paměti představuje badatelské pole, jehož šíři dokumentoval už na konci 90. let Jeffrey Olick [1998]. Tato šíře má co do činění s některými obecnými konceptualizacemi kolektivní paměti, které - jak dokládá Jan Kapusta [2013: 78] - přikládají tomuto pojmu podobný význam, jaký je přisuzován pojmu kultura. Abych se takovému zacházení s pojmy vyhnul, využívám Olickovu definici kolektivní paměti jakožto konceptu zcitlivujícího badatele vůči mnemonickým produktům a praxím [Olick 1999: 346, 2008: 158], tedy vůči praxím a produktům využívaných specificky ke vzpomínání a zpřítomňování minulosti. Je také nutné poznamenat, že tato studie je zaměřena na praxi zpř́itomňování událostí, které informanti většinou neměli možnost zažít. Jde tedy o to, co Marianne Hirsch označuje jako post-memory [Hirsch 2011]. V následujících odstavcích se pokusím nastínit roli médií v myšlenkové tradici zabývající se kolektivní pamětí, a to specificky s ohledem na aktuální proměny mediálních praxí.

V návaznosti na dílo Maurice Halbwachse ${ }^{2}$ rozpracoval Jan Assmann v druhé polovině dvacátého století koncept kolektivní paměti pomocí rozlišení na kulturní a komunikativní pamět'. Podle tohoto autora je Halbwachsova kolektivní pamět ztotožnitelná s tím, co označuje jako komunikativní pamět’ - pamět', která je předávána vyprávěním a je zásadním způsobem svázána se svými lidskými nositeli [J. Assmann 2008: 111]. Assmannův př́nos tak spočívá především v uvedení konceptu kulturní paměti, která je externalizována do symbolických forem, jež přesahují nositele paměti a situace, ve kterých vystupují [J. Assmann 2008: 111]. Kulturní pamět se podle Assmanna odlišuje od té komunikativní také tím, že zpravidla existuje druh aktérů, který se specializuje na její rozvíjení a reprodukci. Komunikativní pamět by v tomto ohledu měla být difúzní [J. Assmann 2008: 114].

Protože je kulturní pamět charakteristická především externalizací do symbolických forem, mluví Jan Assmann také o médiích, která tento typ paměti zpravidla nesou. Jako př́klad uvádí odlišnost jazyka, kterým je nesena „velká“ židovská tradice (hebrejština) od jazyků, které nesou mnohé „menši“ tradice (například jidiš) [J. Assmann 2008: 116]. V návaznosti na to pak Assmann poznamenává, že v moderních společnostech je - s příchodem médií, jako je televizní vysílání - situace komplikovanější [J. Assmann 2008: 117].

\footnotetext{
Dílo Maurice Halbwachse je většinou považováno za základ, na němž stojí celá sociologická tradice zkoumající tento jev. Halbwachs totiž ve své práci otevřel fenomén paměti sociologickému bádání tím, že (v souladu s tezemi Emila Durkheima, jehož vliv na Halbwachsovo dílo dokumentuje Jiří Šubrt [Šubrt - Maslowski Lehmann 2014]) zdůraznil jeho sociální povahu. Podle Halbwachse totiž vzpomínání vždy předpokládá užití jazyka, jakožto společensky vytvářené konvence [Halbwachs 1992: 45]. Jazyk se tak stává nejzákladnějším rámcem pro pamatování. Jako další rámce pak Halbwachs uvádí (do minulosti sahající) vztahy rodinného př́ibuzenství nebo náboženské věrouky obsahující příběhy z minulosti [Halbwachs 1992: 68, 92]. Pamět je v tomto pojetí vždy komunikativně konstituována za pomocí v současnosti existujících rámců. Absence takových rámců pak podle Halbwachse vede k zapomínání [Halbwachs 1992: 172].
} 
Assmann se tématu médií ale už dále nevěnuje a tento aspekt předávání kolektivní paměti zůstával donedávna do značné míry opomíjen. Následující části textu se právě na souvislost mezi mediálními praxemi a předáváním paměti zaměřují, nejprve je však nutné věnovat několik odstavců dalšímu vývoji v konceptualizaci kolektivní paměti.

Koncept kulturní paměti dále rozvíjí Aleida Assmann, a to uvedením dalšího rozlišení, tentokrát mezi kánonem a archivem. Pro vysvětlení těchto konceptů používá Assmann obraz muzea, ve kterém jsou vybírány objekty pro vystavování (kánon), ale v němž se také nachází velké množství dalších objektů uložených ve skladišti a připravených pro vystavení (archiv) [A. Assmann 2008: 98]. Kánon je tedy možné v souladu s pojetím této autorky nahlížet jako aktivní formu paměti, která je selektivně zdůrazněna a je adresovaná určitému publiku. Naproti tomu archiv je v tomto pojetí neadresná, pasivní forma paměti uložená na místě, kam není aktuálně upírána pozornost [A. Assmann 2008: 98]. Co se nenachází $\mathrm{v}$ archivu, je zapomenuto, z čehož vyplývá, že archiv tvoří horizont toho, co lze o historii v daný okamžik vypovídat (a co lze případně kanonizovat) [A. Assmann 2008: 102].

Aleida Assmann také píše o třech oblastech, kde je diference na kánon a archiv uplatňována: náboženství, umění a národní historie [A. Assmann 2008: 101]. Tu poslední se pak ve své aktuální práci snaží překonat konceptem transnacionální paměti, jež s pomocí digitálních technologií a mezinárodních organizačních sítí přesahuje hranice národního státu [Assmann 2014: 546-547]. Astrid Erll v tomto ohledu poznamenává, že se v poslední době objevují konceptualizace kolektivní paměti, které se nacházejí „nad“ nebo „pod“ úrovní národního státu, ke které byla pamět tradičně vztahována [Erll 2011a: 312]. Transnacionální pamět ${ }^{3}$ - tedy pamět’ „nad“ národní úrovní je tomto smyslu doplňována úrovní „pod“ národní pamětí, kde se nacházejí paměti malých komunit, případně (nebo snad především) rodiny.

Význam rodinné paměti Erll spatřuje v tom, že slouží jako jakási „výhybka“ mezi individuální a kolektivní pamětí, tedy mezi osobním autobiografickým vzpomínáním a veřejným vzpomínáním pomocí oficiálních symbolů [Erll 2011a: 313]. Všímá si však také toho, že rodinná pamět nemá kánon, nebo archiv, který by jednoduše existoval, ale že musí být neustále vytvářena komunikací. Z tohoto důvodu je podle Erll rodinná pamět závislá na kontinuitě př́ležitostí pro sdílené vzpomínání [Erll 2011a: 313]. Rodinná pamět, jakožto prostředník mezi individuálním a kolektivním vzpomínáním, je tedy závislá na podnětech, které mohou vzpomínání spouštět. Tyto podněty se často dostávají do rodinného života zprostředkovaně, tedy prostřednictvím médií. V tomto ohledu rozlišuje Harald Welzer čtyři možnosti zprostředkování sociální paměti: autentické záznamy minulosti, kulturní produkci, prostory (architektonické objekty a místa), a přímou interakci mezi aktéry [Welzer 2008: 286-288].

S ohledem na konstatování Jana Assmanna o tom, že moderní média komplikují situaci vzpomínání, se ukazuje, že toto tvrzení platí pro všechny čtyři Welzerovy typy - zvláště pokud mezi moderní média počítáme ta, jež jsou v současnosti označována jako nová,

Podle Erll [2011c: 9] označuje přízvisko „transnacionální“ takový přístup ke studiu paměti, který upouští od předpokladu homogenity kultur a teritorií a který se snaží sledovat mnemonické obsahy např́ič, či mimo sféry tradičně nahlížených kultur. 
nebo přesněji digitální média. ${ }^{4}$ Rozšíření digitálních médií s sebou totiž přináší zmnožení záznamů [Latour 2011: 8] a zpo̊sobů spotřeby kulturní produkce [Macek 2015: 58], zavádí specifický prostor [Cantoni - Tardini 2006: 59] a poskytuje nové možnosti (zprostředkované) interakce [Cantoni - Tardini 2006: 43].

Andrew Hoskins [2009] v návaznosti na tento vývoj píše o „mediatizaci“ paměti, která se podle něj odehrává ve dvou fázích: po období vysílání (broadcast) přichází období nových médií. Audiovizuální média specifická pro první období již byla ve vztahu k fenoménu paměti zkoumána [Edgerton 2001; Landsberg 2004]. Hoskins sám charakterizuje toto období pomocí konceptu „bleskových vzpomínek“ (flashbulb memories), které jsou schopny předat vizuální představy a vyvolat emocionální reakci i když jsou zprostředkované [Hoskins 2009: 34]. Podle Alison Landsberg jsou díky tomu vzpomínky zprostředkované audiovizuálními médii schopné překonávat rámce paměti, jež jsou tradičně tvořeny kolektivitami a v nich rozšířenými přesvědčeními [Landsberg 2004: 8]. Zdá se tedy, že vysílané, nebo promítané vzpomínky mají v tomto ohledu určitý sjednocující potenciál. Landsberg svoji teorii buduje v historickém kontextu Spojených států amerických. Otázkou však zůstává, zda a jak je tato teorie uplatnitelná také v kontextu českém.

Důsledky uplatnění nových médií ve druhé fázi popisovaného vývoje už ale Hoskins tak uceleně necharakterizuje a navrhuje pouze několik otázek, jimiž by se budoucí výzkum v této oblasti měl zabývat [Hoskins 2009: 36] . ${ }^{5}$ Výzkum paměti v této oblasti se zatím zaměruje spíše na specifické vlastnosti digitálních médií, promítající se do způsobů uchovávání informací jako takových [Dvořák 2014; Mayer-Schönberger 2009]. Ve vztahu ke zprostředkovávání kolektivního vzpomínání na minulost se jedná o oblast stále ještě málo probádanou. ${ }^{6}$ Proto je nutné v této oblasti navázat na výzkum sledující vývoj mediálních praxí $\mathrm{v}$ obecné rovině.

Nová média s sebou zatím nepřináší ony revoluční důsledky, které jsou jim často přisuzovány [Macek 2015: 35, 48]. Takové důsledky měl přinést fakt, že poprvé v historii je nastupující generace lepší v ovládání aktuálních technologií, než generace stávající [Lupač 2015: 151]. Tento předpoklad je problematický minimálně ve dvou ohledech. Za prvé, jak argumentují Ellen Helsper a Rebeca Enyon, generace obecně nevykazují takovou míru homogenity, aby je bylo možné posuzovat jako celky [Helsper - Enyon 2009: 14]. Za druhé, jak ukazuje Petr Lupač, rozšíření a užívání informačních technologií není jen otázkou fyzické dostupnosti zařízení, ale především otázkou schopností technologie využívat a vyhodnocovat nalezené informace [Lupač 2015: 122]. Opět se zde objevuje určující role praxí v rámci mediálních celků. Podle Macka se však v této oblasti odehrává proměna, jejímž důsledkem je, že spotřeba mediálních obsahů přestává být časoprostorově vázána, využívá více zdrojů informací a začíná být obousměrná (tedy přestává být jednoduše spotřebou) [Macek 2015: 31].

4 Novými médii a jejich reflexí v sociálněvědním diskurzu se podrobně ve své dizertační práci zabýval Jakub Macek. Podle tohoto autora je tento typ médií často charakterizován kromě své digitální povahy také interaktivitou a těsným vztahem s počítačovými sítěmi [Macek 2013: 19].

5 Jde především o otázky po tom, jak je mediální obsah navozující vzpomínky vytvářen, jak na sebe různé mediální obsahy navazují, a především jak se tyto procesy mění s decentralizací způsobenou nastupujícími novými médii.

6 Dílčí výzkum v této oblasti provedl Karger [2016]. Systematické výzkumné zaměření do této oblasti však zatím, jak se zdá, chybí. 
Určité vodítko pro orientaci v této komplikované situaci mohou poskytnout praxe aktérů, kteří se s takto nepřehlednou situací každodenně vyrovnávají. V tomto ohledu identifikuje Macek v návaznosti na Jiř́iho Fialu [2012: 62] několik typů tzv. kurační praxe: 1) expertní kuraci v rámci které provádí specializovaná skupina aktérů výběr mediálních obsahů tak, jako například při klasickém televizním či rozhlasovém vysílání [Kaderka Havlík 2010]; 2) sociální kuraci, která spočívá v diskuzích a doporučeních mezi aktéry-diváky, at už tyto diskuze probíhají osobně, nebo zprostř̌edkovaně některou z forem digitální komunikace, jako jsou například sociální sítě; 3) datově konzultační kuraci, jejímž současným základem je využívání online databázových zdrojů (jako jsou vyhledávače, nebo webové stránky specializující se na poskytování informací například o filmech a seriálech) za účelem výběru, př́ípadně zprostředkování obsahů [Macek 2015: 88]. Takto identifikované typy mediální kurace lze považovat za strategie, které aktéři využívají k orientaci v situaci, do níž pronikají média stále složitějším zpơsobem.

Termínem kurace se podrobněji zabývá Krista Kennedy [2016], která si všímá aktuální popularity tohoto pojmu, zejména s ohledem na používání v sousloví „digitální kurace“. V tomto smyslu pak podle této autorky pojem ztrácí mnohé ze svého původního významu, který zahrnuje také aktivní rešeršování, kategorizaci a vytváření kompozic. Kennedy dokonce s odkazem na Andreu Lunsford [2006: 171] srovnává kuraci s vytvářením textu. V populárním jazyce se však podle Kennedyové často kurace zaměňuje za prostou selekci a agregaci [Kennedy 2016: 180]. Z tohoto hlediska odpovídá původnímu významu slova především expertní kurace. Na druhou stranu nelze považovat aktivity, jako jsou sociální a datově konzultační kurace za prostou selekci a agregaci. Aktéři při nich také rešeršují informační zdroje (televizní program, výsledky vyhledávání, apod.) a vytváŕí kompozice (vybírají a srovnávají webové stránky, doplňují sledovaný obsah vlastním vyprávěním, apod.). ${ }^{7}$

Mnozí autoři [např́íklad A. Assmann 2008: 101; Hroch 2014: 52; Šubrt 2011: 140] chápou kolektivní pamět jako proces selektivního zdůrazňování různých částí a aspektů historie. Doprovodným jevem této selektivity je, že objekty zprostředkující minulost jsou bud' izolovány a vyjmuty z dosahu veřejnosti (tak jako např́klad muzejní exponáty), nebo jsou kontrolovaně reprodukovány a masově distribuovány [Guggenheim 2009: 44]. Pokud však je cílem selektivitu kolektivní paměti podrobněji zkoumat, nelze se vyhnout konceptualizaci praxe, která ji v každodenním životě ztělesňuje. ${ }^{8}$ Selektivní rozměr mnemonických praxí je možné zachytit jako praxe kurační, $v$ rámci kterých aktéři vytvářejí specifické kompozice médií a jejich obsahů. Kurace se tak jeví jako vhodný zcitlivující koncept pro zkoumání praxe selektivního budování paměti. Badatelský přistup orientovaný tímto konceptem se zaměřuje na způsoby jednání a na prostředky či podmínky, jež umožňují intertextualitu, intermedialitu, či remediaci a dobře tak zapadá do jednoho z klíčových výzkumných programů memory studies, jak je identifikovala Erll [2011b: 1].

$\mathrm{V}$ předchozích odstavcích jsem se pokusil alespoň rámcově zachytit onu komplikovanost, kterou Jan Assmann naznačil ve vztahu k moderním médiím a která dále průběžně

7 Nelze také pominout metaforickou souvislost termínu kurace, který je tradičně vázán na instituce, jako jsou muzea (jejichž prostředím např́íklad Aleida Assmann [2008] ilustruje rozdíl mezi kánonem a archivem) s tématem paměti a vzpomínání.

8 Např́klad Chana Teeger a Vereda Vinitzky-Seroussi [2007] se ve své práci zaměřovaly př́mo na kurační praxi muzea Apartheidu v Jižní Africe. 
narůstá s rozšiřováním médií digitálních. Role médií se zdá být důležitá nejen ve vztahu ke kulturní paměti (jejíž symboly jsou často médii zprostředkovány), ale i komunikativní rodinné paměti, která je na podnětech z médií často závislá. Jak ale v současnosti aktéři využívají médií pro vzpomínání - a jaké kurační strategie přitom používají - je otázka empirická a v tuzemském prostředí málo probádaná. Proto je cílem tohoto textu začít odpověd' na tuto otázku rozkrývat, a to prostřednictvím mapování situací vzpomínání u generace žáků a studentů. Je totiž možné oprávněně předpokládat, že praxe zahrnující digitální média se bude hojně objevovat právě v nižších věkových kategoriích populace. ${ }^{9}$ Zároveň je tak možné sledovat proces socializace či vrůstání nové generace do kolektivní paměti.

\section{Situační analýza}

Metodologickým přístupem, jenž je uplatňován v této studii, je situační analýza. Adele Clarke rozvinula tento prŕstup v návaznosti na metodologickou tradici zakotvené teorie [Clarke 2003, 2005, 2015; Clarke - Friese - Washburn 2015]. Z této tradice situační analýza dědí principy jako konstantní komparaci, nebo teoretické vzorkování. Liší se však tím, že představu kontextu (jež se v tradičních přístupech projevovala prostřednictvím konceptu podmínek jednání) nahrazuje konceptem situace. Podle Clarke je možné najít všechny podmínky a prostředky jednání právě v situaci [Clarke - Friese 2014]. Ta se stává základní analytickou jednotkou jejího př́stupu. Z tohoto důvodu jsou také tradiční postupy zakotvené teorie doplněny o vytváření situačních map, které slouží jak pro účely analýzy (tř́idění jednotek, načrtávání vztahů v rámci map), tak pro vizualizaci zkoumaného jevu.

Základní analytické úrovně, které situační analýza rozlišuje, jsou v zásadě tři: analýza situace, analýza sociálních arén a poziční analýza. V této studii budu pohybovat především na první úrovni, což je v souladu se záměrem zkoumání situací předávání paměti z pohledu aktérů. $\mathrm{V}$ tomto ohledu není cílem studie sbírat různé útržkovité záznamy o tom, jak informanti vykreslují historické události, nýbrž jde o identifikaci a konceptualizaci vzorců mnemonické praxe informantů v situacích jejich každodenního života. Řečeno Olickovým slovníkem, jde o zkoumání kolektivní paměti (collective memory), ne shromážděných pamětí (collected memories) [Olick 1999].

Analyzovaná data pochází z 11 ohniskových skupin, které se odehrály v prosinci 2015 a v únoru 2016. Při konstrukci vzorku bylo cílem dosáhnout co největší rozmanitosti informantů v rámci formálního vzdělávacího systému, a proto vzorek pokrývá všechny tři úrovně formálního vzdělávání (primární, sekundární, terciární). Na každé úrovni pak byla snaha dále rozšiřit vzorek na různé typy škol (střední odborné školy a gymnázia), nebo typy vzdělání (humanitní a technické vysokoškolské obory). Ve vzorku se tak nacházejí data z jedné základní školy ( 2 ohniskové skupiny), jedné střední odborné školy (3 ohniskové skupiny), jednoho gymnázia ( 2 ohniskové skupiny) a jedné vysoké školy ( 2 ohniskové skupiny na technických oborech a 2 ohniskové skupiny na humanitních oborech). Výsledný vzorek přehledně zachycuje následující tabulka:

9 Tuto skutečnost dokládá ve své práci např́iklad Macek [2015: 79, 62, 80]. 
Vzorek ohniskových skupin

\begin{tabular}{|c|c|c|}
\hline Typ školy & Věk & $\mathrm{N}$ \\
\hline Základní & $12-14$ & $21(10 \check{\mathrm{Z}}, 11 \mathrm{M})$ \\
\hline Střední & $13-20$ & $46(23 \check{\mathrm{Z}}, 23 \mathrm{M})$ \\
\hline Vysoké & $23-25$ & $21(10 \check{\mathrm{Z}}, 11 \mathrm{M})$ \\
\hline
\end{tabular}

Průběh ohniskových skupin byl strukturován podle logiky významných historických událostí: 11. záŕí 2001, 17. listopad 1989, srpen 1968, únor 1948. ${ }^{10}$ Dotazování týkající se každé z událostí bylo zahájeno kolováním několika fotografií zachycujících danou historickou událost. Po prohlédnutí fotek byli informanti dotazováni v souladu s jednotným scénářem (viz př́loha) na to, jaké informační zdroje ve vztahu k událostem používají (nebo by mohli používat) a jaký význam událostem přikládají. Scénář ohniskových skupin byl pro analyzovaná data jednotný, protože šlo o první vlnu sběru dat a teoretické vzorkování bylo uplatněno jen v omezené míře ( $v$ rámci kladení důrazu a podrobnějšího doptávání na jednotlivé aspekty otázek definovaných ve scénáŕi). V tomto ohledu jde o studii explorativní, zachycující první výsledky bádání.

\section{Mediální kurace a mnemonické praxe}

V následujících odstavcích se pokusím zachytit, jak jednotlivé typy mediální kurace prostupují různé mnemonické praxe. $\mathrm{V}$ této oblasti je potřeba se vyhnout předpokladu svázanosti mediálních obsahů s jejich nosiči. V současném mediálním prostředí může být např́klad obsah televizního vysílání zprostředkován internetovými stránkami a tak se tyto kategorie stávají nejednoznačnými. To by činilo analýzu orientující se podle jednotlivých informačních zdrojů problematickou. Proto je následující část textu členěna podle jednotlivých typů mediální kurace. Takové členění se orientuje podle toho, jakým způsobem se mladí lidé k mediálním obsahům dostávají a odpovídá tak lépe záměru zachytit relevantní mediální celky v jejich celistvosti.

\section{Expertní kurace}

Ačkoli se věnuje pozornost primárně současnému dění, zpravodajství produkované televizními stanicemi se ukázalo být jedním z nejvýznamnějších případů expertní kurace s mnemonickým rozměrem. Především pro nejstarší věkovou kohortu našeho vzorku (studující na VŠ) bylo zpravodajství klíčovým zdrojem informací o teroristických útocích z 11. září 2001. Tato kohorta totiž byla v době, kdy se událost odehrála ve věku, kdy již samostatně sledovala televizní vysílání. Její členové jsou si schopni vybavit konkrétní

10 Teroristické útoky z 11. září 2001 byly do scénáře ohniskových skupin zahrnuty proto, že se jedná o výraznou, mediálně hojně pokrytou událost, kterou informanti často zažili v útlém věku, nebo se v té době teprve narodili. Jedná se tedy o událost, která je na půli cesty v opouštění žitého světa zkoumané generace a je tak zamýšlena jako výchozí bod pro srovnání s ostatními událostmi jednoznačně náležejícími do minulosti, jež musela být informantům zprostředkována. 
televizní záběry, hudbu, která byla pouštěna k sestřihům a celkovou situaci sledování vysílání. Působivost audiovizuální reprodukce události dokázala navodit intenzivní emocionální odezvu. O tom svědčí i reakce Hany ${ }^{11}$ na otázku jak se o události dozvěděla:

Mně se to třeba vybavuje, když ukazovali v televizi obrázky lidí, jak utíkali od padajících dvojčat. A tak mi to přišlo... pro mě to byl hrozný šok. Napřed jsem tomu vủbec nevěřila, že se něco takového stalo. Takže pro mě to byl hrozný šok a úplně mi bylo těch lidí líto. Těch, kteří z toho místa utíkali, a já jsem sama z toho byla ve stresu, takže jsem se cítila docela špatně. (Hana, VŠ)

Hana ve své reakci zdůrazňuje silnou roli překvapení - šoku způsobeného tím, že si do té doby nedokázala takovou událost ani představit. V návaznosti na to se dostavily pocity stresu a lítosti. Takto silná emocionální odezva ale automaticky neznamená, že si informantka nese tuto událost v každodenním povědomí. Hana mluví o něco později o tom, že nad událostí běžně vůbec nepřemýšlí, i když to byl v té době podle jejích slov silný zážitek.

Zajímavé jsou v tomto ohledu reakce ostatních informantek ve stejné ohniskové skupině na tutéž otázku. Ačkoli se explicitně nevymezují vůči odpovědi Hany, podávají výrazně odlišný obraz situace, která emocionální reakci nepřipouští, a spíše zdůrazňují roli později se objevujících zdrojů informací, jež měly také často audiovizuální povahu:

Já si spíš vybavuji, že v té době, to už je dost let zpátky, mě to bylo asi jedno. V té době, to bylo něco, co se nestalo tady, ale jinde, $v$ Americe. Až ted', oni vlastně opakují... nějaké dokumenty kolem toho běží. Tak až ted’ jsem se o to zajímala, ale tehdy určitě ne. (Lenka, VŠ)

Já si to vybavuji, i ten den prímo si vybavuji, ale že bych se o to zajímala tehdy, to asi ne. Ale s postupem času, když vznikaly ty konspirační teorie, tak možná potom. (Jana, VŠ)

Zdůrazňování pozdějších zdrojů informací se objevuje jako vzorec i v dalších ohniskových skupinách se stejně starými participanty. Ti si podle svých slov vybudovali zájem o událost až na základě její zpětné tematizace. Jak naznačují ve svých výpovědích Jana i Lenka („oni opakuji“, „vznikají teorie“), tato tematizace nevychází z iniciativy informantek, nýbrž představuje něco, s čím se bez ohledu na svou vůli setkávají v médii nasyceném prostředí. Svou roli v tom však nesehrával jen mediální obsah referující přímo o událostech 11. zárí, nýbrž také obsah reprezentující aktuální události, které podle participantů patří ke stejnému typu události: následné teroristické útoky spojované s radikálním islamismem.

I aktuální události - v době konání ohniskových skupin reagovali participanti na teroristické útoky, jež se odehrály v listopadu 2015 v Pařriži - tedy mají mnemonický rozměr a mohou aktérům připomínat zlomové události, které považují za počátek určitého dění. Tato mnemonická praxe se navíc zformovala i u mladších věkových kohort, které původní událost samy nezažily. V tomto ohledu představuje 11. září (v souladu s oficiálním narativem) všeobecně vnímanou diskontinuitu. Každý další teroristický útok pak pro aktéry implicitně odkazuje k této prvotní události. A protože se poslední teroristické útoky odehrály na území Evropy, zvyšuje se také relevance tohoto typu událostí, což se projevuje emocionální odezvou - strachem a obavami. Tato odezva se projevovala především v reakci na otázku, co si z události dotazovaní odnášejí:

11 Jména uváděná v tomto textu jsou smyšlená. 
Asi existenci té hrozby. Nemusí to být New York, může to být Praha. (Petr, gymnázium)

Člověk se nemůže cítit bezpečně nikde a nikdy, prostě to přišlo z ničeho nic a nikdo nic nečekal. (Jakub, VŠ)

Uvedeným reakcím předcházelo $\mathrm{v}$ ohniskových skupinách vyjádření nízké relevance události od jiných participantů. Je tedy možné uvedené úryvky považovat za vymezování se vưči takovému stanovisku. $\mathrm{V}$ jedné $\mathrm{z}$ ohniskových skupin (ZŠ) začali navíc participanti spontánně diskutovat míru relevance historických událostí, na které jsme se ptali. Bylo př́iznačné, že se diskuze o relevanci objevila, když se tazatel podle scénáře přesunul k dotazování na události srpna 1968. Diskuze se pak rychle stočila k posuzování, zda je relevantněǰí 11. záŕí 2001, nebo 17. listopad 1989. Zatímco první z událostí byla vnímána jako nejmladší a tudíž nejaktuálněǰsí, relevance druhé z nich byla argumentována významem specifickým pro Českou republiku. Relevance listopadu 1989 (jakožto „naší události) nakonec $\mathrm{v}$ ohniskových skupinách převážila, ale diskuze, která k tomuto výsledku vedla, vypovídá mnohé i o tom, jak je vnímáno 11. záríí. Vyjednávání relevance 11. září vůči 17. listopadu (jiná událost ze scénáře patrně nebyla považována za podobně relevantní) totiž poukazuje na to, jak je prostorová bariéra, která dříve pro aktéry odstiňovala hrozbu teroristických útoků $\mathrm{v}$ současné době překonávána podobnými událostmi. Vzhledem $\mathrm{k}$ tomu, že z pohledu aktérů existuje mezi původní událostí a těmi následnými těsná souvislost, je možné uvažovat o zpětném zvyšování relevance události. Taková interpretace by byla v souladu s výše uvedenými úryvky o postupném budování zájmu o událost.

Otázka relevance historických událostí pro mládež má ale, jak již bylo naznačeno, význam nejen pro poměřování důležitosti „našich“a „jejich“ událostí, ale projevuje se také ve vztahu ke stárí jednotlivých událostí. V ohniskových skupinách se objevovalo téma relevance, doprovázené reflexí možností vcítění se do dřivější doby tím naléhavěji, čím hlouběji do historie jsme v rámci scénáře dospěli. První náznaky tematizace těchto problémů se objevovaly už u 17. listopadu, jakožto události, kterou žádný z informantů neměl možnost zažít. Nejintenzivněji se pak tyto problémy projevovaly ve vztahu k nejstarší události, kterou scénár zahrnoval - k únoru 1948. S pohybem směrem ke starším událostem se také $\mathrm{z}$ reakcí $\mathrm{v}$ ohniskových skupinách postupně vytrácely některé informační zdroje. Zatímco informace o 11. záŕí získávali informanti z televizního vysílání, internetových stránek, rodinného vyprávění, diskuze s vrstevníky, nebo během školního vyučování, ve vztahu $\mathrm{k}$ únoru 1948 už v této roli vystupuje jen matně vybavované školní vyučování a př́ležitostné vyprávění rodičů a prarodičũ. Zdá se tedy, že počet využívaných informačních zdrojů jde ruku v ruce s reflektovanou relevancí a možností vcítění se do dřívější doby.

Tento vzorec vystupuje nejzřetelněji ve vztahu ke školnímu vyučování, které je jakožto státem zřízený expertní zdroj informací vystaveno vysokému očekávání. Role školního vzdělávání je vnímána jako v ideálním př́ípadě soběstačná - zprostř̌edkující vše, co vzdělávaný potřebuje vědět. Na tomto očekávání je pak založena kritika, kterou adresovaly vzdělávacímu systému informantky $\mathrm{v}$ závěru jedné z ohniskových skupin:

Hana: Ale na základní škole, já mám mozek na data, prostě jsem se to naučila a pamatovala jsem si to, ale potom už mi to nepřišlo důležité. Na základní škole, stř̌ední škole mi to přišlo jenom jako předávání fakt. Prostě co se stalo, stalo se to, to, to, ale nikdo nás do toho nevtáhl. A třeba tady se objevují nové postupy, nové metody vyučování a i [vyučující] nás do toho vtáhne. Prožijeme si to, navíc jsme starší. 
Magda: Líp se to pamatuje, protože to podává takovou formou, že to člověka zaujme.

Hana: Ano.

Jana: Jo.

Hana: Než na základní škole. Já si třeba pamatuju, jak jednou učitel došel v plátnu, na hlavě měl věnec a zdravil nás, že je Caesar a to si pamatuju do dneška. To bylo něco, to byl zážitek. Smáli jsme se mu, že tak přišel, ale on to bral jako formu výuky a tak nás do toho vtáhl. (VŠ)

Do této kritiky se patrně promítá specifická reflexivita získaná studiem pedagogicky zaměřeného oboru. To však neznamená, že by se kritika institucionalizovaného vzdělávání objevovala jen v této ohniskové skupině. V tomto prrípadě však byly informantky schopny podrobněji artikulovat své stanovisko. Faktickou znalost, kterou zprostředkovává škola, považují za nedostatečnou, protože jí chybí rozměr prožívání a v důsledku tak nevede k trvalému osvojení. Škola by podle jejich stanoviska měla zprostředkovávat nejen faktické znalosti, ale také zážitky, jež by žákům umožňovaly se do doby vcítit. V souvislosti s tím informantky mluví o nových didaktických metodách a o současných či minulých vyučujících, kteří je do výuky o historických událostech dokázali vtáhnout. Jejich didaktický přístup pak považují za ideál naplňující představu školy jakožto soběstačného zdroje informací o minulosti.

Rozšíríme-li však svůj pohled za hranice institucionalizovaného vzdělávání, můžeme najít jiné zprostředkovatele historických událostí, které vcítění podporují. Výše uvedená tendence postupného vytrácení relevance u starších událostí byla v jednom př́ípadě narušena, a to další významnou formou expertní kurace objevující se v našich datech - filmy natočenými na náměty souvisejícími s událostmi srpna 1968. Během ohniskových skupin v tomto kontextu zazněly tituly jako Pelišky, Rebelové, Hořící keř, nebo Kolja a objevily se také zmínky o seriálu Vyprávěj. Participanti pak deklarují, že filmy slouží jako hlavní zdroj vizuálních představ, které si vybaví, když je událost tematizována. V některých př́padech pak explicitně reflektují filmy jako zdroj emocionálních podnětů vztahujících se k události. Michaela v reakci na otázku kam by se obrátila, kdyby chtěla o události vědět víc, uvádí následující zdroje:

Internet, ptala bych se rodičů, prarodičů a myslím, že na tuto tematiku je dost dobře natočených spousta českých filmů, takže tak jako pocitově jak to tak mohlo probíhat v té době jako, myslím, že je dobré se podívat na nějaký film. (Michaela, VŠ)

Z informačních zdrojů, které uvádí, mluví Michaela nejpodrobněji právě o filmech. Z úryvku je také patrné, že považuje filmy za vhodný zdroj emocí, i když uvažuje o vyprávění rodičů a prarodičů. Ostatně, vyprávění obecně nebylo v ohniskových skupinách explicitně spojováno se vcítěním se do dané doby, a to ani v př́ípadech, kdy byly tematizovány osobní zážitky rodičů či prarodičů. Tento vzorec je nejvíce viditelný v momentech, kdy jsou současně tematizovány filmy i vyprávění. Např́iklad Jitka v reakci na otázku, jestli jí o událostech srpna 1968 někdo vyprávěl, ř́íá:

Babička ř́kala, že to má spojené, protože asi jedenáct hodin na to se narodila moje mamka, takže to mělo zase úplně jiný rozměr, protože nevěděla co se děje. Ale můj první kontakt, nebo spíš kdy jsem se o tom dozvěděla, asi z filmu Rebelové, kde je vlastně krásně ukázaný takový ten zlom... a pak taky ze seriálu Vyprávěj. (Jitka, Gymnázium) 
Jitka svou reakcí navázala na výpovědi svých spolužaček, které mluvily pouze o vyprávění prarodičů, nebo rodičů. První větou pak zprostředkovává pocity, jež podle vyprávění zažívala její babička. Sama se k nim ale explicitně nevztahuje. O sobě začíná mluvit až v následující větě, kde popisuje první kontakt s událostí a uvádí film, kde je událost „krásně ukázaná“. Odkazuje tím k vizuální stránce předaných informací a oceňuje jejich názornost, čímž dává najevo určující význam tohoto média. Zdá se proto, že filmy a seriály tímto způsobem plní nezastupitelnou roli zprostředkovatele vizuálních představ a emocionálních podnětů vztahujících se $\mathrm{k}$ historickým událostem. Při existenci dostatečného množství těchto audiovizuálních děl jsou filmy schopny dokonce narušovat obecný vzorec vytrácení relevance a možností vcítění se do aktérů zažívajících zachycené události. V tomto ohledu odpovídají uvedené poznatky tezi Alison Landsberg [2004] o působení vzpomínek vizualizovaných ve filmech. Jak ale bude patrné dále, tato teze je v českém kontextu limitována souhrou s mnemonickou praxí sociální kurace.

\section{Sociální kurace}

Patrně nejryzejší formu sociální kurace můžeme pozorovat u mladších věkových kohort. Ve vztahu k událostem 11. září mluví jejich členové o zprostředkování informací rodiči. Událost totiž bud' vůbec nezažili, nebo ji zažili v období, kdy v domácnosti neměli přístup k ovládání televize, a tak obsah, který viděli, byl vybírán rodiči. Není překvapující, že u mladších věkových kohort nebyly vůbec tematizovány intenzivní emocionální reakce, které u některých členů starších kohort následovaly po zhlédnutí nejvypjatějších záběrů. Studující základních i středních škol mluví o tom, že první ucelené informace o události jim vyprávěli rodiče v návaznosti na tematizaci události například během výročí, nebo v souvislosti s aktuálním děním.

A právě vyprávění představuje klíčový prvek sociální kurace ve vztahu ke všem historickým událostem zahrnutým do scénáře. Obsah vyprávění se věnuje vykreslování podmínek života $\mathrm{v}$ době, kdy se historické události odehrály, nebo přímo osobním zážitkům souvisejícím s danými událostmi. Zdá se, že v tomto ohledu hraje důležitou roli osobní biografie vyprávějícího, která určuje, jestli zažil určitou událost, jak dlouhý čas žil v určitých podmínkách a hlavně, v jaké biografické fázi výše zmíněné prožil. Vyprávěné zážitky pak souvisí s historickými událostmi bud' příčinností (událost zážitek přímo způsobila), nebo souběhem (osobní zážitek se časově překrývá s událostí).

Zde se také ukázal podstatný rozdíl mezi vyprávěním prarodičů a rodičů. Ti první vypráví podle informantů spontánně, bez potřeby explicitního podnětu. To může souviset se skutečností, že prarodiče obvykle nesdílí společnou domácnost se svými vnoučaty a proto pro ně může představovat dostatečný podnět už jejich přítomnost. V případě rodičů se však setkáváme s tím, že jejich vyprávění zpravidla reaguje na podněty explicitnější povahy, jako je mediální tematizace události během výročí, společné sledování filmů, nebo na to navazující konkrétní otázky jejich dětí. Tyto souvislosti artikulují informantky na jedné z ohniskových skupin ve vztahu k událostem srpna 1968:

Tazatel: Vybavujete si zhruba, kdy jste se o té události dozvěděli? Když si vezmeme ty filmy, tak v kině nebo spíš doma u televize? 
Lenka: Doma u televize, to si pamatuju, že jsem se mamky nebo tatky ptala, co tam dělá ten tank, jako proč tam je a dostala jsem jenom odpovědi no, protože nás obsadili Rusáci, tečka. Ř́íkám aha super, to jsem se toho dozvěděla. A pak v té škole no.

Tazatel: Uvažujete někdy o tom srpnu 68 , co se stalo?

Lenka: Ne.

Magda: Ne, asi spíš v návaznosti na ten film, když to člověk viděl. Tak si řekl, jaká asi ta doba byla a co to pro ty lidi znamenalo. A že když jsme tam viděli třeba ty tanky, že to muselo byt tehdy těžké. Jako ten šok.

Tazatel: Co v případě vás ostatních, uvažujete taky v takovém kontextu jako vaše spolužačka? To znamená třeba s tím konfrontováním ve filmu, nebo v televizi?

Hana: Já to mám taky tak. Ale třeba i ty informace, když se dívám na nějaký film a vlastně vidím ty události, tak v té návaznosti se třeba ptám, doptávám rodičů nebo tatkky a tím vlastně dostávám ty informace. Protože sama bych o tom nepřemýšlela, že bych se jednou ráno probudila a řekla si jak to asi bylo, jdu se zeptat, to ne. Jakože po zhlédnutí nějakého filmu a pak se doptávám. Ale jinak o tom nepřemýšlím nijak. (VŠ)

Informantky v této ohniskové skupině popisují situace, v nichž se o historické události dozvídaly. Pro srpen 1968 je příznačné, že v těchto situacích hrají důležitou roli filmy, které nejen že zprostředkovávají emocionální podněty svým recipientům, ale představují také podněty pro komentáře a vyprávění. Filmy jsou totiž zpravidla sledovány kolektivně (nebo alespoň v kontextu kolektivních vazeb), což vytváŕí podmínky pro sociální kuraci. Filmy tak nepůsobí jen prrímo svým obsahem, ale význam událostí, které zachycují, může být v různé míře dále předáván a interpretován v rámci situací jejich sledování. Podobnou tendenci lze nalézt ve způsobu, jakým si informanti postupně budovali zájem o události 11. zář́i 2001. Tento proces byl doprovázen interakcí mezi vrstevníky - at' už spočívala ve výměně informačních materiálů, či v diskuzích o konspiračních teoriích.

$\mathrm{V}$ tomto ohledu nelze pominout rozšírenost alternativních narativů a konspiračních teorií, které byly tematizovány v každé z ohniskových skupin. Tyto narativy však nespočívají pouze v obměňování viníků teroristických útoků, ale také v přidávání dalšího časového rozměru události. Jak ukazují Jiří Nekvapil a Ivan Leudar, oficiální vyjádření se vyhýbala historickému vysvětlení události a zaměřovala se spíše na artikulaci vzniku nové historické etapy [Nekvapil - Leudar 2010: 629]. Tento oficiální obraz se odráží v mnohých promluvách participantů, jež označují 11. září za zlomovou událost, jež značí př́íchod nové éry. Takový obraz diskontinuity je však běžně doplňován či přímo konfrontován s alternativními narativy, které se zaměřují právě na př́ičiny teroristického útoku. Vrstevnické skupiny tak rovněž tvoří prostředí, ve kterém jsou informace z mediálních zdrojů kontextualizovány $-\mathrm{v}$ tomto př́padě prostřednictvím konfrontace oficiálních a alternativních narativů o události.

Takové působení sociální kurace vytváří určitou limitaci teze Alison Landsberg [2004: 8] o sjednocujícím potenciálu vzpomínek zprostředkovaných pomocí audiovizuálních médií. Protetické vzpomínky měly být podle této autorky schopny překonávat Halbwachsem identifikované rámce paměti, jako je rodina, třída, nebo náboženská komunita a vytvořit představy sdílené napříč původními rámci. Landsberg tuto tezi demonstrovala na př́ípadech vzpomínek, jejichž předávání tradičními kanály, jako je rodina nebo komunita, bylo z nějakého důvodu přerušeno [Landsberg 2004: 2]. V takových situacích působí na recipienty pouze audiovizuální obsah. Ve mnou zkoumaných mnemonických 
praxích však vystupují pamětníci a další „kurátoři“ z řad významných druhých, kteří audiovizuální obsah rámují, komentují, doplňují a interpretují. Obsah zde pak působí spíše jako zdroj tematizace, prvotní podnět a ne jako jediný zdroj informací o události. Praxe sociální kurace tak, zdá se, má potenciál limitovat míru unifikace představ o minulosti, kterou ve vztahu k audiovizuálním médiím předpokládá Landsberg.

\section{Datově konzultační kurace}

Masové rozšíření internetové infrastruktury v posledních dekádách vytvořilo podmínky také pro uplatňování kurace datově konzultační, která, jak bylo výše uvedeno, spočívá ve využívání platforem agregujících digitální data. Nejvýraznější charakteristikou tohoto typu kurace jsou podle nashromážděných dat výrazné rozdíly mezi vnímaným potenciálem a jeho aktuálním využíváním. Role internetu a jím zprostředkovaných informačních zdrojů vyznívala nejsilněji, když se scénář ohniskové skupiny zaměřoval na potenciální informační zdroje (otázka „Kam byste se obrátili, kdybyste se o události chtěli dozvědět víc?"). V těchto momentech se využívání sítě zdálo být téměř univerzální strategií pro získávání dalších informací. V některých případech docházelo také k explicitní reflexi této preference:

Dnes už je stejně všechno o internetu, když člověk chce něco zjistit, tak asi málo lidí zajde do knihovny nebo do města, aby našel nějaké dokumenty z té doby. (VŠ)

Pro popis potenciálního využívání tohoto zdroje je však příznačné, že participanti nejsou schopni mluvit o svém postupu př́liš podrobně. Uvádějí tak pouze první krok, který zpravidla spočívá v zadání dotazu do vyhledávače, nebo na specifické platformě jako je například Wikipedie. Tuto tendenci můžeme alespoň částečně přičítat interaktivitě internetu jakožto zprostředkovatele vyhledávání. Aktéři v tomto ohledu nemohou předjímat výsledky svého vyhledávání a rozhodují se podle toho, co jim vyhledávače nabídnou. Druhým vysvětlením však může být také to, že internet není ve skutečnosti ke specificky mnemonickým účelům využíván. Lze totiž pozorovat diskrepanci při srovnání deklarací o potenciálním využívání internetu s odpověd’mi, jež během ohniskových skupin popisovaly skutečně využívané zdroje.

Tato diskrepance spočívá v tom, že skutečně využívané internetové zdroje jsou konkrétní povahy a aktéři se úmyslně připojují př́mo k nim (na rozdíl od vyhledávání). Internetové platformy uváděné jako skutečné zdroje jsou však zaměřeny zejména na zprostřredkování informací o současnosti. Jde především o sociální sítě jako Facebook, víceúčelové domovské stránky jako Seznam.cz, nebo zpravodajské weby. Tyto platformy nemají specificky mnemonickou povahu a informace o historických událostech se na ně dostávají pouze skrze asociace s aktuálním děním (například při výročích). Zdá se tedy, že participanti ohniskových skupin nejsou zvyklí využívat internet ke specificky mnemonickým účelům a informace, které na síti nacházejí, jsou spíše vedlejším efektem jejich každodenních aktivit.

Při tematizaci internetových zdrojů se během ohniskových skupin běžně objevoval také problém důvěryhodnosti. Participanti si uvědomují, že nemohou věřit všem informačním zdrojům a proto uplatňují různé strategie, aby informace, které získávají, mohli považovat 
za důvěryhodné. Nejviditelnějším aspektem těchto strategií, je to, že se aktéři ve svém každodenním využívání informačních zdrojů vymezují vůči těm, které a priori považují za nedůvěryhodné. Do této kategorie spadají zdroje, které jsou označovány jako „plátky“, nebo „bulvár“. Zaznamenali jsme také analogické výpovědi o zdrojích, které jsou považovány za „oficiální“ a tudíž důvěryhodné.

To, že aktéři třídí informační zdroje a obracejí se primárně na ty, které považují za důvěryhodné, není překvapující. Problematika důvěryhodnosti však začne být zajímavější, když jsou aktéři konfrontováni s nutností vytvořit si o určité události celkovou představu, kdy nemohou spoléhat na dílčí informace, jež přináší jimi rutinně využívané platformy. V takový moment přicházejí ke slovu internetové vyhledávače a strategie jsou vyjadřovány pomocí kritérií, jež aktéři využívají (nebo by využívali) pro srovnávání a výběr ze zobrazených výsledků. V tomto ohledu aktéři nesrovnávají jen důvěryhodnost zdroje, ale také některé vlastnosti textu (jako jeho rozsah a podrobnost) a jeho obsah (opakující se informace jsou považovány za důvěryhodnější). Otázku, do jaké míry je tento typ reflexivity mezi aktéry rozšířen a jestli jsou takto deklarované strategie uplatňovány v praxi, však tento text nemůže zodpovědět. Zaměřím se proto na obecnější rovinu konstrukce důvěryhodnosti.

Už samotný fakt nejednoznačnosti některých historických událostí a existence alternativních narativů šírících se hlavně prostřednictvím internetových platforem podněcuje aktéry k reflexi. Na jedné straně může vést taková situace $\mathrm{k}$ rezignaci na možnost vytvořit si bezrozpornou představu o události. Jako ilustrace této možnosti může posloužit př́pad 11. záríí, který bývá komentován tak, že se „asi ani nikdy nedozvíme, jak to tehdy doopravdy bylo“ (Jana, VŠ). Rezignace se však nemusí vázat jen na události, v datech se objevuje podobný vztah také ke specifickému typu médií, konkrétně k internetovým zdrojům jako takovým. Ve vztahu k událostem srpna 1968 se taková pochybnost projevila na jedné z ohniskových skupin se studujícími vysoké školy:

Tazatel: Kam byste se dneska obrátili, kdybyste o tom roku 68 chtěli vědět víc?

Jana: Já to nezměním, knížky, tatka.

Hana: U mě je to taky tatka.

Lenka: Já bych na internetu hledala nějaké zprávy o tom, nějaké odkazy, nebo literaturu, nebo další zdroje.

Magda: Já bych asi taky hledala přes knížky, protože tehdy psalo hodně autorů, kteří byli cenzurovaní a psali o tom režimu, o změnách a tak.

Jana: Navíc z toho důvodu, já ten internet moc ne, protože ono je dneska takový trend tu historii dost př̌krucovat, tak jak se to hodí dneska politickým stranám. Tak vůbec, z toho důvodu knížky a tatka. (VŠ)

K takovému postoji ale existuje i analogický protiklad. V závěru ohniskové skupiny se stř̌edoškolskými žáky se v reakci na otázku po dalších relevantních událostech rozvířila diskuze o migraci jako aktuálním politickém tématu:

Lukáš: Připadá mi, že některé motivy komunismu a těch totalitních režimů se začínají vracet. Že za prvé nám Evropa diktuje co dělat a co si myslet a začíná se projevovat cenzura a manipulace.

Tazatel: V čem se projevuje ta cenzura a manipulace?

Lukáš: Manipulace informací třeba když byla nějaká demonstrace v Polsku, tak noviny o tom psaly, že tam bylo pár tisíc lidí a přitom tam podle zdrojủ z internetu bylo pár set tisíc lidí, takže to je taková velká manipulace. A nebo že takoví ti vysoce postavení lidé se mi zdá, že se snaží 
manipulovat, abychom podlehli tomu co přináší migrace, abychom se začali přiklánět $\mathrm{k}$ islámu a připadá mi to špatně a moc lidí si to neuvědomuje. (SŠ)

Mnohost verzí historických událostí, kterou je možné mezi internetovými zdroji najít, odrazuje některé aktéry od důvěřování jejich obsahu. V promluvách jiných informantů se navíc projevuje pochybnost o tom, že internetové zdroje jsou schopny podávat autentické informace o událostech starších než je toto médium. Aktéři pak volí strategii využívání tradičnějších zdrojů, jako jsou knihy (byt i k nim se mohou dostávat prostřednictvím vyhledávání na internetu), nebo vyprávění rodičủ. Ta stejná mnohost je ale jinými aktéry považována za podmínku dosažení pravdivých informací. Tento postoj je spojený s představou, že tradiční média sledují skrytou agendu nastavenou za určitým cílem. Prostředí internetu, kde se mohou prosazovat i alternativní narativy, pak pro tyto aktéry představuje způsob korekce zkreslení tradičních médií.

Ve světle výše napsaného se vytrácí ona revolučnost, která je novým médiím často připisována ( $\mathrm{a}$ jejíz kritiku jsem nastínil $\mathrm{v}$ jedné $\mathrm{z}$ předešlých částí textu). Nejenže se $\mathrm{v}$ rámci nových médií nerozšiřuje žádná specificky mnemonická praxe a využívání tohoto typu médií pro zmíněné účely se tak nachází především v podobě nenaplňovaného potenciálu. Aktuální využívání nových médií je v reflexích aktérů vztahováno k médiím tradičním. At už nová média představují nedůvěryhodný labyrint různých verzí historie, nebo svobodný informační prostor fungující bez skryté agendy, nenahrazují, ale spiše doplňují roli tradičních médií. $\mathrm{O}$ to důležitější se pak zdá být znalost konkrétních kuračních praxí, protože způsoby, jakými aktéři vytvářejí své vlastní mediální kompozice, se značně liší.

\section{Diskuze}

V souhrnném pohledu na výše uvedená zjištění (základní přehled situací vzhledem $\mathrm{k}$ jednotlivým událostem poskytuje schéma níže) je možné si povšimnout různé míry institucionalizace jednotlivých informačních zdrojů. Data tak umožňují nahlédnout proces institucionalizace předávání informací o konkrétních událostech. Nejlépe je tento proces viditelný ve srovnání výpovědi různých věkových kohort vzhledem $\mathrm{k}$ událostem 11. září 2001. Zatímco nejstarší kohorta (studující VŠ) je schopna si vybavit svůj vlastní prožitek ze sledování dobového televizního vysílání, u mladších kohort se již v této roli nalézá zprostředkování vyprávěním rodičů, nebo dokonce školním vyučováním. Při srovnání jednotlivých historických událostí mezi sebou je zase možné pozorovat vytrácení se méně formalizovaných zdrojů informací, čím hlouběji do historie se dostáváme. Zatímco mladší události jsou vedle školního vyučování tematizovány a zprostředkovány vyprávěním rodičůu, filmy a seriály, př́padně dokonce diskuzemi mezi vrstevníky, u nejstarší události převládá školní vyučování doplňované vyprávěním.

S ohledem na rodinnou pamět odpovídají výše uvedená zjištění tezi Astrid Erll [2011a: 313], která tvrdí, že tento druh paměti je závislý na kontinuitě př́ležitostí pro sdílené vzpomínání. Nelze však předpokládat, že rodiče budou sledovat všechny mediální obsahy ve svém okolí a reagovat na ně vyprávěním. V tomto ohledu se expertní kurace setkává se sociální, a to především ve formě výběru sledovaných filmů a seriálů, nebo ve formě přisuzování významů různým výročím. $Z$ tohoto pohledu by bylo možné revidovat tvrzení Erll [2011a: 313] o neexistenci archivu a kánonu rodinné paměti. Za archiv je totiž možné 
v určitém smyslu považovat relevantní mediální obsahy, které jsou veřejně distribuovány a za kánon pak ty, kterým je v rodině věnována pozornost, př́ípadně na základě nichž dokonce dochází k vyprávění. ${ }^{12}$

Je však také potřeba poznamenat, že zprostředkovatelé představ o minulosti objevující se v promluvách našich participantů mají v určitém smyslu homogenní povahu. Zdá se, že jejich pamět' (nebo přesněji postpamět') je budována především pomocí zprostředkovatelů multiplikovaných, a ne izolovaných [Guggenheim 2009]. At̉ už jde o př́mé působení audiovizuálních médií na prožívání aktérů, nebo nepřímé působení různých mediálních obsahů jako podnětů pro diskuze a vyprávění, roli multiplikovaných zprostředkovatelů v tomto procesu nelze popřít. O to více vyniká absence zprostředkovatelů izolovaných, jakými jsou např́klad muzejní exponáty, památná místa, pomníky apod. Důvodem, proč tento typ zprostředkovatelů v reflexích mládeže absentuje, může být náročnější dostupnost těchto objektů, které musí aktéři zpravidla záměrně vyhledávat. Na rozdíl od multiplikovaných zprostřredkovatelů se tak s těmi izolovanými mládež nesetkává v rámci svého každodenního života.

Konečně, je potřeba také zdůraznit roli, kterou hrají audiovizuální média vzhledem ke zprostředkování emocionálního vcítění se do historického období, či události. Toto působení je pozorovatelné především ve vztahu k událostem, jež se aktérů bezprostředně nedotkly (at̉ už z důvodu distance prostorové, nebo časové), ale které byly zároveň hojně mediálně zprostředkovány. $\mathrm{V}$ tomto ohledu se ukázaly být obzvláště příkladné události 11. záŕí 2001 a srpna 1968, at už pro svá filmová ztvárnění, nebo prostor věnovaný v televizním vysílání obecně. I když je působení audiovizuálních médií rámováno sociální kurací, během analýzy se neobjevil silnější zdroj emocionality. Zjištění, že multiplikované audiovizuální obsahy jsou reflektovány jako hlavní zprostředkovatel vcítění v situaci, kdy se uvažuje např́iklad i o autentickém vyprávění členů vlastní rodiny se může zdát paradoxní. Alison Landsberg [2004: 33] však poukazuje na to, že je třeba v tomto ohledu rozlišovat mezi autenticitou a zkušeností. Jinými slovy, co je autentické, nemusí být spojeno se zkušeností, kdežto zkušenost nemusí být vždy autentická. Zatímco pamětníci mají autentickou zkušenost s historickou skutečností (kterou však jako takovou nemohou předat jinak než pomocí mluveného slova), audiovizuální média poskytují sice ne-autentickou, ale zato pro publikum skutečnou zkušenost vlastního prožitku. Sjednocující potenciál audiovizuálních médií tak spočívá ve sdílené zkušenosti prožitku z jejich zhlédnutí.

\section{Závěr}

Cílem této studie bylo zachytit základní elementy situací vzpomínání a předávání představ o minulosti. Vzájemná hluboká provázanost těchto elementů tvořících spíše konfigurace mediálních celků, než agregát izolovaných informačních zdrojů se ukázala být zásadní charakteristikou prolínající se celou analýzou. Systematické zohledňování této provázanosti se ve vztahu k předchozímu zkoumání atomizovaných zdrojů informací o minulosti ukázalo být strategií lépe zachycující žitou zkušenost aktérů. S ohledem na předpoklady

12 Tyto obsahy však ve vztahu k rodině tvoří jen část toho, co lze považovat za kánon a archiv paměti. Dalším médiem, které se nachází mimo tematické zaměření této studie, je např́iklad rodinná fotografie. Tomuto médiu se ve svých studiích podrobněji věnovaly Barbora Spalová [2013: 10] a Jindra Tichá [2010: 98]. 


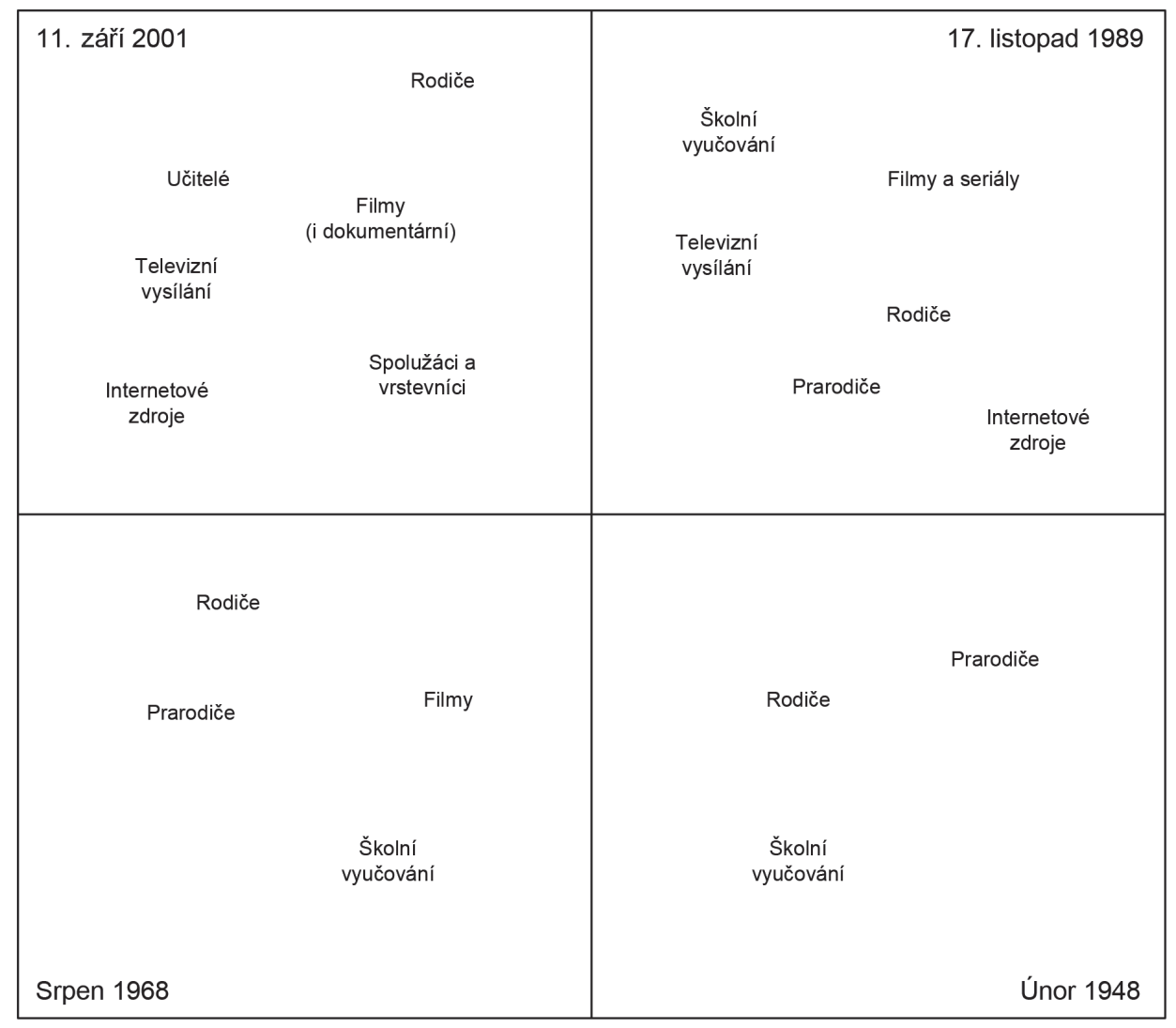

Srovnání situačních map skutečně využívaných zdrojů informací pro jednotlivé události

o roli nových médií v procesu přenosu představ o minulosti se jejich užívání kontextualizované $\mathrm{v}$ prostředí tradičních médií nezdá již tak revoluční. Tato zjištění představují první kroky na cestě k rozkrývání odpovědí na otázky, které ve vztahu k významu nových médií pro fenomén kolektivní paměti nastínil Andrew Hoskins [2009: 36].

Klíčovým nástrojem k uchopení uvedené provázanosti mediálních celků se ukázal být koncept kurace [Kennedy 2016; Macek 2015]. Jde o zcitlivující koncept, který sice nepredstavuje systematickou teoretickou syntézu, ale tím, že zohledňuje obě strany známé sociologické dichotomie, ${ }^{13}$ dobře zachycuje zkoumané empirické skutečnosti. Na jedné straně totiž tento koncept nepředpokládá, že veškerý obsah paměti (a především postpaměti) si aktéři rekonstruují samostatně ex nihilo. Na druhé straně ale také nepředpokládá, že aktéři jen reprodukují veřejně sdílené diskurzy. Aktivní role aktérů spočívá v tom, že si vybírají, doplňují a kontextualizují své zdroje informací, představ a pocitů. Jinými slovy, že využívají již existujících narativů a mediálních obsahů, ze kterých prostřednictvím specifické

13 V obecné rovině jde o antinomii aktéra a struktury. Ve vztahu k fenoménu kolektivní paměti ji Jiří Šubrt [2011] uchopil jako antinomii paměti individuální a kolektivní. 
kurační praxe vytvářejí své vlastní kompozice. V tomto bodě už však tato studie naráží na své vlastní limity. Data z ohniskových skupin neposkytují hlubší vhled do vytváření a udržování konfigurací mediálních celků. Budoucí výzkum by se tak mohl zaměřit na zachycení jejich základních typů ve vztahu k relevantním charakteristikám svých nositelů.

\section{Literatura}

Assmann, Aleida [2008]. Canon and Archive. In. Erll, Astrid - Nünning, Ansgar (ed.). Cultural memory studies: An international and interdisciplinary hand-book. Berlin: Walter de Gruyter, s. 97-108.

Assmann, Aleida [2014]. Transnational Memories. European Review 22 (4): 546-556.

Assmann, Jan [2008]. Communicative and Cultural Memory. In. Erll, Astrid - Nünning, Ansgar (ed.). Cultural memory studies: An international and interdisciplinary hand-book. Berlin: Walter de Gruyter, s. $109-118$.

Burzová, Petra - Dvořáková, Ilona - Hejnal, Ondřej - Růžička, Michal - Toušek, Laco [2013]. Pamět a prostor: Reprezentační strategie společenstva vzpomínání v postindustriálním městě. Sociální studia / Social Studies 10 (4): 107-126.

Cantoni, Lorenzo - Tardini, Stefano [2006]. Internet. New York: Routledge.

Clarke, Adele [2003]. Situational Analyses: Grounded Theory Mapping After the Postmodern Turn. Symbolic Interaction 26 (4): 553-576.

Clarke, Adele [2005]. Situational Analysis: Grounded Theory After the Postmodern Turn. Thousand Oaks, CA: Sage.

Clarke, Adele [2015]. From Grounded Theory to Situational Analysis. What's New? Why? How? In. Clarke, Adele - Friese, Carrie - Washburn, Rachel (ed.). Situational analysis in practice: Mapping research with grounded theory. Walnut Creek, CA: Left Coast Press, s. 84-118.

Clarke, Adele - Friese, Carrie [2014]. Grounded Theorizing Using Situational Analysis. In. Clarke, Adele - Charmaz, Kathy (ed.). Grounded theory and situational analysis. situational analysis: Essentials and exemplars. London: SAGE, s. 67-90.

Clarke, Adele - Friese, Carrie, - Washburn, Rachel [2015]. Situational Analysis in Practice: Mapping Research with Grounded Theory. Walnut Creek, CA: Left Coast Press.

Dvořák, Tomáš [2014]. Přepisování paměti. In. Maslowski, Nicolas - Šubrt, Jiří (ed.). Kolektivní pamět: K teoretickým otázkám. Praha: Karolinum, s. 170-176.

Edgerton, Gary [2001]. Television Histories: Shaping Collective Memory in the Media Age. Lexington: The University Press of Kentucky.

Erll, Astrid [2011a]. Locating Family in Cultural Memory Studies. Journal of Comparative Family Studies 42 (3): 303-318.

Erll, Astrid [2011b]. Traumatic Pasts, Literary Afterlives, and Transcultural Memory: New Directions of Literary and Media Memory Studies. Journal of Aesthetics \& Culture 3 (1): nestránkováno.

Erll, Astrid [2011c]. Travelling Memory. Parallax 17 (4): 4-18.

Fiala, Jiří [2012]. Nelegálně distribuované video z hlediska mediální etnografie. Mediální studia 6 (1): 60-75.

Fine, Gary Alan - Beim, Aaron [2007]. Introduction: Interactionist Approaches to Collective Memory. Symbolic Interaction 30 (1): 1-5.

Gracová, Blažena - Labischová, Denisa [2012]. Současná teorie a praxe dějepisného vzdělávání na školách. Pedagogická orientace 22 (4): 516-543.

Guggenheim, Michael [2009]. Building Memory: Architecture, Networks and Users. Memory Studies 2 (1): 39-53.

Halbwachs, Maurice [1992]. On Collective Memory. Chicago: University of Chicago Press.

Helsper, Ellen - Enyon, Rebeca [2009]. Digital Natives: Where Is the Evidence? British Educational Research Journal 36 (3): 1-18.

Hirsch, Marianne [2011]. The Generation of Postmemory. In. Olick, Jeffrey - Vinitzky-Seroussi, Vered Levy, Daniel (ed.). The collective memory reader. Oxford: Oxford University Press, s. 346-348. 
Hoskins, Andrew [2009]. The Mediatisation of Memory. In. Garde-Hansen, Joanne - Hoskins, Andrew Reading, Anna (ed.). Save as. digital memories. New York: Palgrave Macmillan, s. 27-43.

Hroch, Miroslav [2014]. Pamět a historické vědomí očima historika. In. Maslowski, Nicolas - Šubrt, Jiří (ed.). Kolektivní pamět: K teoretickým otázkám. Praha: Karolinum, s. 46-65.

Kaderka, Petr - Havlík, Martin [2010]. Vytváření televizních zpráv: pracovní postupy v systému žánrových norem. Sociologický časopis / Czech Sociological Review 46 (4): 537-567.

Kapusta, Jan [2011]. Vtělení paměti a minulosti do svatojakubské cesty a společensko-vědního diskurzu. Historická sociologie (2): 75-94.

Karger, Tomáš [2016]. Velehrad on Wikipedia: Religious Memory in the Digital Realm. Pantheon 11 (1): $32-48$.

Karger, Tomáš [2017]. Explanační principy ve studiu kolektivní paměti: Kultura, kognice a jejich situovanost. Historická sociologie (2): 23-40.

Kennedy, Krista [2016]. Textual Curation. Computers and Composition 40 (1): 175-189.

Kunštát, Daniel [2010]. Pluralita paměti a komunistická minulost: Česká veřejnost a její reflexe roku 1989 a polistopadového vývoje. Naše společnost (Our Society) 8 (1): 29-39.

Kunt, Gergely - Szegö, Dóri - Vajda, Júlia [2013]. Politická komunikace v př́ibězích zneuctěných památníků. Sociální studia / Social Studies 10 (4): 35-56.

Labischová, Denisa [2012]. Factors Shaping the Historical Consciousness of Pupils, Students and Teachers in Czech Schools. The New Educational Review 29 (3): 148-61.

Landsberg, Alison [2004]. Prosthetic Memory: The Transformation of American Rememberance in the Age of Mass Culture. New York: Columbia University Press.

Latour, Bruno [2011]. Networks, Societies, Spheres: Reflections of an Actor-Network Theorist. International Journal of Communication 5 (1): 796-810.

Lunsfrod, Andrea [2006]. Writing, Technologies, and the Fifth Canon. Computers and Composition 23 (2): 169-77.

Lupač, Petr [2015]. Za hranice digitální propasti: Nerovnost v informační společnosti. Praha: SLON.

Macek, Jakub [2013]. Poznámky ke studiím nových médií. Brno: Masarykova univerzita.

Macek, Jakub [2015]. Média v pohybu: K proměně současných českých publik. Brno: Masarykova Univerzita.

Mayer-Schönberger, Viktor [2009]. Delete: The Virtue of Forgetting in the Digital Age. Princeton: Princeton University Press.

Nekvapil, Jiří - Leudar, Ivan [2010]. Znovu k 11. 9. 2001: Jak se „dělá historie“ v politickém diskurzu. Sociologický časopis / Czech Sociological Review 46 (4): 619-642.

Oláh, Gábor [2013]. Kolektivní pamět, prostor a významy. Případ náměstí Svobody v Budapešti. Sociologický časopis / Czech Sociological Review 49 (5): 729-750.

Olick, Jeffrey [1999]. Collective Memory: The Two Cultures. Sociological Theory 17 (3): 333-348.

Olick, Jeffrey [2008]. From Collective Memory to the Sociology of Mnemonic Practices and Products. In. Erll, Astrid - Nünning, Ansgar (ed.). Cultural memory studies: An international and interdisciplinary hand-book. Berlin: Walter de Gruyter, s. 151-162.

Olick, Jeffrey - Robbins, Joyce [1998]. Social Memory Studies: From „Collective Memory“ to the Historical Sociology of Mnemonic Practices. Annual Review of Sociology 24 (1): 105-140.

Spalová, Barbora [2013]. Rodinné paměti v pohraničí. Familiarismus v pohledu do minulosti. Biograf 58 (1): $1-71$.

Šmídová, Olga [2010]. Pro nás lépe už bylo... Vymístění z velké historie a kolektivní pamět „českých Němcü“. Sociální studia / Social Studies 7 (1): 59-87.

Šubrt, Jiř́ [2011]. Antinomie sociální paměti. Sociológia 43 (2): 133-157.

Šubrt, Jiří - Pfeiferová, Štěpánka [2010a]. Kolektivní pamět jako předmět historicko-sociologického bádání. Historická sociologie (1): 9-29.

Šubrt, Jiří - Pfeiferová, Štěpánka [2010b]. Nástin teoreticko-sociologického př́stupu k otázce historického vědomí. In. Šubrt, Jiří (ed.). Historické vědomí jako předmět badatelského zájmu: Teorie a výzkum. Kolín: Historická sociologie - knižní řada, s. 21-30.

Šubrt, Jiří - Vinopal, Jiří [2010]. K otázce historického vědomí obyvatel České republiky. Naše společnost 8 (1): 9-20.

Šubrt, Jiří - Vinopal, Jiří [2013]. Historické vědomí obyvatel České republiky perspektivou sociologického výzkumu. Praha: Karolinum. 
Šubrt, Jiří - Maslowski, Nicolas - Lehmann, Štěpánka [2014]. Maurice Halbwachs, koncept rámců paměti a kolektivní paměti. In. Maslowski, Nicolas - Šubrt, Jiří (ed.). Kolektivní pamět: K teoretickým otázkám. Praha: Karolinum, s. 15-30.

Šubrt, Jiří - Vinopal, Jiří - Vávra, Martin [2013]. The Czechs and Their View of History. European Societies 15 (5): 729-752.

Teeger, Chana - Vinitzky-Seroussi, Vered [2007]. Controlling for Consensus: Commemorating Apartheid in South Africa. Symbolic Interaction 30 (1): 57-78.

Tichá, Jindra [2010]. V odrazu našich vzpomínek. Rodinná amatérská fotografie jako nástroj paměti. Sociální studia / Social Studies 7 (1): 89-100.

Vávra, Martin [2013]. Zdroje, z nichž se vytvářejí představy o historii. In. Šubrt, Jiř́́ - Vinopal, Jiří (ed.). Historické vědomí obyvatel České republiky perspektivou sociologického výzkumu. Praha: Karolinum, s. 39-45.

Welzer, Harald [2008]. Communicative Memory. In. Erll, Astrid - Nünning, Ansgar (ed.). Cultural memory studies: An international and interdisciplinary hand-book. Berlin: Walter de Gruyter, s. 285-300.

Tomáš Karger působí jako akademický pracovník v Centru výzkumu Fakulty humanitních studii Univerzity Tomáše Bati ve Zlínè. Je autorem knihy The Weight of the Intangible: Knowledge Networks in Free and Open Source Software Development, která je založena na jeho dizertační práci zabývající se etnografickým studiem projektů svobodného softwaru. Doktorské studium oboru sociologie absolvoval na FF UP v Olomouci v roce 2015. Jeho jednotící badatelský zájem představuje téma produkce a prenosu vědění, a to v rüzných oblastech, jako jsou vývoj technologií, vědecké poznávání, nebo kolektivní pamèt. 


\section{Příloha}

\section{Scénář ohniskových skupin}

\section{A) Představení výzkumu}

- O čem náš výzkum je a k čemu slouží

- Jak bude výzkum probíhat

- Souhlas s podmínkami výzkumu

- Projít níže uvedenou sadu otázek pro každou z následujících událostí:

- 11. záŕí 2001

- 17. listopad 1989

○ srpen 1968

○ únor 1948

\section{B) Otázky}

(Nechat kolovat fotky zachycující událost)

- Tematický okruh: přenos

○ Jak jste se o dané události dozvěděli?

- Jaký informační zdroj?

- Jak jste na první informaci reagovali?

- Jak vypadá vaše typické používání tohoto informačního zdroje?

- Pro jaké účely informační zdroj typicky využíváte?

○ Vyprávěl vám o události někdo?

- Kdo vám vyprávěl?

- Při jaké příležitosti?

- Bylo to opakovaně?

- Jak jste na vyprávění reagovali?

- Kam byste se obrátili, kdybyste o ní chtěli vědět více?

- Už jste si někdy takto něco dohledávali?

- Jak vypadá vaše typické používání tohoto informačního zdroje?

- Tematický okruh: význam

- Uvažujete někdy o této události?

- Pokud ano, co je spouštěčem?

- Setkáváte se se spouštěčem opakovaně?

- V jakých situacích se se spouštěčem setkáváte?

- Jak na spouštěč reagujete?

○ Co si vybavíte, když se řekne 11. záŕí 2001?

- Co o události víte?

- Jak událost hodnotíte? Bylo to dobře, nebo špatně?

○ Co pro vás z této události vyplývá?

- Je událost ještě aktuální/relevantní?

- Můžeme si z ní odnést nějaké ponaučení?

- Dalo by se toto ponaučení zobecnit v nějaké pravidlo? 